\title{
Long Memory and Parity Reversion in Real Exchange Rate
}

\author{
ABD. GHAFAR ISMAIL ${ }^{1}$ \\ Faculty of Economics \\ Universiti Kebangsaan Malaysia \\ WAHI ISMAIL ${ }^{2}$ \\ Faculty of Economics \\ Universiti Teknologi Mara
}

\begin{abstract}
This paper examines the post Bretton Woods experience of the Malaysian Ringgit. In this period, Malaysia moved from a managed to a floating exchange rate environment. We examine persistence in real exchange rates by estimating fractionally integrated ARIMA models and find evidence of long memory, which induces persistence though this long memory need not be associated with a unit root. The results show that three out of four exchange rates being examined display mean reversion. The long memory process re-establishes the Purchasing Power Parity as a meaningful concept of long-run equilibrium relation between the exchange rate and relative prices.
\end{abstract}

\begin{abstract}
ABSTRAK
Kajian ini cuba melihat gelagat siri masa kadar pertukaran benar Ringgit Malaysia dalam tempoh pasca Bretton Woods. Dalam tempoh ini, rejim kadar pertukaran bertukar dari sistem berasaskan Dolar Amerika kepada kadar pertukaran terapung. Pendapat umum di kalangan kajian semasa ke atas pariti kuasa beli tempoh selepas Bretton Woods adalah terlalu singkat untuk mempamerkan sebarang ciri kembali kepada min dalam siri kadar pertukaran. Adakah ini benar? Jawapannya, sebagaimana yang ditunjukkan dalam kajian ini bergantung kepada ujian statistik yang digunakan. Teknik semi-parametrik telah digunakan untuk menguji ciri-ciri siri masa kadar pertukaran efektif dan kadar pertukaran bilateral. Model ARFIMA didapati mempunyai kuasa untuk mengesan kembali kepada pariti walaupun dengan saiz sampel yang kecil. Keputusan empirik membuktikan bahawa terdapat ciri kembali kepada pariti dalam tempoh selepas Bretton Woods yang menerangkan hubungan keseimbangan jangka panjang antara kadar pertukaran dan harga relatif sebagaimana yang diterangkan oleh hipotesis kesataraan kuasa beli
\end{abstract}

JEL classification: C23; F31;

Keywords: purchasing power parity; exchange rate; mean reversion; stationary tests;

\footnotetext{
${ }^{1}$ Professor of banking and financial economics, Universiti Kebangsaan Malaysia

${ }^{2}$ Lecturer of economics, Universiti Teknologi MARA Kota Kinabalu
} 


\section{INTRODUCTION}

The stationarity of real exchange rates is an issue that has long bedeviled researchers in international finance. In the case that real exchange rates are non-stationary, the principle of purchasing power parity (PPP) is no longer valid as a representation of the long run equilibrium relation between exchange rates and relative prices.

The failure to detect parity reversion in real exchange rates has often been attributed to the relatively short-span of data employed, which covers only the post-Bretton Woods float. Standard tests take the unit root as the null hypothesis, and the power to reject this null hypothesis is extremely low using data from the post-Bretton Woods period alone, which spans 29 years or less. It does not help that the data are often sampled at monthly or quarterly frequency, as the power of the unit root test depends on the data's span, rather than its frequency (Shiller \& Perron, 1985; Hakkio \& Rush, 1991).

Two responses to the problem of low power appear in the PPP literature. First, a number of studies employ panel data from the post-Bretton Woods float. As shown by Frankel \& Rose (1996), panel techniques can greatly improve the power of the unit root test. Indeed, many panel studies find support for long-run PPP for the postBretton Woods era, including Oh (1996), Wu (1996), Papell (1997), and Taylor \& Sarno (1998). The second response to low power in the PPP literature is the use of long spans of data, often covering more than a century. For example, Abuaf \& Jorion (1990), Glen (1992), and Lothian \& Taylor (1996) all use long spans of data to test longrun PPP. Both the panel and long spanning data studies show that deviations from long-run PPP are quite persistent and display near unit root behavior, precisely the type of stationary behavior that will be difficult for standard single-country tests to detect for samples as short as the modern float.

This paper revisits the issue of whether real exchange rates are stationary over the flexible rate period. Given the many studies such as Baharumshah \& Ariff (1997), Khoon \& Mithani (2000), and Azali, Habibullah \& Baharumshah
(2001), that have been made on the empirical validity of PPP, it is pertinent to ask what is the value added contributed by this paper. This paper extends previous research in a number of directions. First, most studies of PPP are based on univariate methods applied to bilateral exchange rates. This paper departs from the norm in that we employ both bilateral exchange rates and a real effective exchange rate (REER). Second, the paper aims to address some of the concerns regarding the robustness of the unit root test for mean reversion by applying the semi-parametric estimate of $d$, the degree of fractional integration.

\section{TESTING FOR MEAN REVERSION}

If the PPP hypothesis is valid then shocks to real exchange rates have finite lives. To illustrate this point, it is useful to write the PPP relation as containing the long run equilibrium real exchange rate $r_{\mathrm{t}}$ and short run deviations from this equilibrium level:

$$
r_{\mathrm{t}} \equiv \mathbf{r}_{\mathrm{t}}+\left(r_{\mathrm{t}}-r_{\mathrm{t}}\right)
$$

where $r_{\mathfrak{t}^{\prime}}=e_{t}-\left(p_{t}^{*}-p_{\mathfrak{t}^{\prime}}\right)$. If relative PPP holds in the long run, $r_{t}$ will be constant and ultimately have the same values as $r_{t}$ In such a case $e_{\mathrm{t}}, p_{\mathrm{t}}^{*}$ and $p_{\mathrm{t}}$ will achieve equilibrium values. Empirically however, there is no reason why $r_{t}$ should not deviate from $r_{t}$. If shocks to $\mathrm{r}_{t}$ have finite lives, then long run PPP is a valid equilibrium.

There is always an inherent difficulty when testing for the persistence of shock in finite data, namely that data which exhibits slow mean reversion may be indistinguishable from the data where the shocks have infinite persistence. For this reason, researchers investigating PPP often prefer to work with data that span a century or more. Our focus in this paper, however, is on the post-Bretton Woods period and this entails the risk that our testing methodology may lack the power to distinguish between finite and infinitely-lived shocks, a point noted by Frankel (1986); Huizinga (1987), and Diebold et al. (1991).

Mean reversion in economic time series depends crucially on correlations at long lags, 
which can easily be miss specified in simple ARIMA representations. We assert, however, that what is required is a generalization of the ARIMA model that can capture a variety of long run, low frequency responses.

The conventional dynamic model for the real exchange rate is the ARIMA $(p, d, q)$ process:

$$
\phi(B)(1-B){ }^{\mathrm{d}} r_{\mathrm{t}}=\delta+\theta(B) \varepsilon_{\mathrm{t}},
$$

where $\mathrm{B}$ is the lag operator, $\mathrm{B} r_{\mathrm{t}}=r_{\mathrm{t}-1}, \phi$ $(B)$ and $\theta(B)$ are polynomials in the lag operator whose roots lie outside the unit circle, $\delta$ is a constant and $d$ is an integer, usually zero or one. Diebold et al. (1991) and Cheung \& Lai (1993) apply the more general ARFIMA $(p, d, q)$ corresponding to equation (2) where $d$ may take on non-integer values. The ARFIMA model be- longs to the class of long-memory processes, sonamed for their ability to display significant dependence between observations widely separated in time. Standard ARIMA processes are often labeled 'short-memory' processes because the dependence between observations $\tau$ periods apart decays rapidly as $\tau$ increases. Indeed, it is wellknown that for large $\tau$ ARIMA autocorrelations decay approximately geometrically,

$$
\rho(\tau) \sim r^{\tau},
$$

where $r$ is a constant such that $|r|<1$. ARFIMA processes, however, have a slower hyperbolic autocorrelation decay; for large $t$ we have the approximation

$$
\rho_{Y}(\tau) \sim \tau^{2 d-1}, \quad d<1 / 2, \quad d \neq 0 .
$$

Table 1

A Comparison Result of the $\tau$-th Order Autocorrelations

\begin{tabular}{|ccccccccccc|}
\hline & \multicolumn{10}{c|}{$\operatorname{Lag}(\tau)$} \\
\cline { 2 - 10 } & 1 & 2 & 3 & 4 & 5 & 10 & 25 & 50 & 100 \\
\hline$(1-0.5 \mathrm{~L}) \mathrm{Y}_{t}=\varepsilon_{t}, \rho(\tau)=$ & 0.50 & 0.25 & 0.13 & 0.06 & 0.03 & 0.00 & 0.00 & 0.00 & 0.00 \\
$(1-\mathrm{L}){ }^{0.3} \mathrm{Y}_{t}=\varepsilon_{t}, \rho(\tau)=$ & 0.50 & 0.40 & 0.35 & 0.32 & 0.30 & 0.24 & 0.18 & 0.14 & 0.11 \\
\hline
\end{tabular}

Sources: Adopted from Diebold \& Rudebusch (1989)

Table 1 provides a comparison of the $\tau$-th order autocorrelations of fractional noise with those of a first-order auto-regression [AR(1)]. The two models are parameterized to provide the same first order autocorrelations, but as the interval between observations increases, the autocorrelations diverge. At lag 25, the AR (1) correlation is approximately 0 , while the fractionally integrated series has a correlation of 0.18 .
The concept of long memory, when applied to $r_{\mathrm{t}}$, corresponds to a situation in which

$$
\lim \sum\left|\rho_{j}\right|=\infty,
$$

where $\rho_{j}$ is the autocorrelation coefficient at lag $j$ for $r_{t}$. A popular method of capturing the type of behavior defined in equation (3) is the 
fractionally differenced time series model of Granger (1980). In this case $r_{t}$ satisfies:

$$
\text { (1- B) }{ }^{\mathrm{d}} r_{t}=\varepsilon_{\mathrm{t},} \varepsilon_{\mathrm{t}} \sim \text { i.i.d. }\left(0, \sigma^{2} \varepsilon\right) .
$$

Granger shows that:

$$
(1-\mathrm{B}){ }^{\mathrm{d}} r_{t}=\sum \mathrm{A}_{\mathrm{k}} \mathrm{r}_{\mathrm{t}-\mathrm{k}}=\varepsilon_{\mathrm{t}}
$$

where the AR coefficient $A_{k}$ is in terms of the gamma function

$$
\operatorname{Ak}=(-1)^{\mathrm{k}}(d / k)=\Gamma(k-d) / \Gamma(-d) \Gamma(k+1) .
$$

For $|d|>1 / 2$, the variance of $r_{t}$ is infinite and hence $r_{t}$ is non-stationary and has long memory. For $-1 / 2<d<1 / 2$ the process is stationary and has long memory. We use two-step procedure proposed by Geweke \& Porter-Hudak (GPH) (1983) to estimate $d$. The spectral density of $r_{t}$ is given by:

$$
\begin{aligned}
& f_{\mathrm{r}}(\lambda)=|1-\exp (-\mathrm{i} \lambda)|^{-2 \mathrm{~d}} f_{\varepsilon}(\lambda)= \\
& {\left[4 \sin ^{2}(\lambda / 2)\right]^{-\mathrm{d}} f_{\varepsilon}(\lambda),}
\end{aligned}
$$

where $f_{\varepsilon}(\lambda)$ is the spectral density of $\varepsilon_{t^{\prime}}$. It follows that:

$$
\ln \left[f_{\mathrm{r}}(\lambda)\right]=\ln \left[f_{\varepsilon}(\lambda]-d \ln \left[4 \sin ^{2}(\lambda / 2)\right] .\right.
$$

The particular utility of equation (8) is its formal similarity to a simple linear regression equation:

$$
\ln \left[f_{\mathrm{r}}(\lambda)\right]=\beta_{0}+\beta_{1} \ln \left[4 \sin ^{2}(\lambda / 2)\right] .
$$

GPH proposes estimation of $d$ by regressing the first $\mathrm{n}(\mathrm{T})$ values from the sample periodogram of $r_{t}$, on the corresponding functions of the first $n(T)$ frequencies of spectral density. Here $n(T)$ is taken to be reasonably small; GPH suggests $n(T)=T^{\alpha}$, obtaining good results with $\alpha$ $=0.5$. Baillie (1987) comments that the GPH estimator is potentially robust to non-normality, however; there is reasonable evidence to suggest bias and inefficiency in small samples.

The data used in this study consist of monthly observations for the real exchange rate between the Malaysian ringgit and the US dollar, the Singapore dollar and the British pound; and the real effective exchange rate sampled monthly over the period 1988-2002. The data were transformed into $\log$ arithms $r_{\mathrm{t}}=\log \left(R_{\mathrm{t}}\right)$.

\section{EMPIRICAL RESULTS}

As an initial assessment, the data are subjected to augmented Dickey-Fuller tests for unit roots and the hypothesis could not be rejected as shown in Table 2.

Table 2

ADF Unit Root Test

\begin{tabular}{|lcccc|}
\hline & \multicolumn{2}{c}{ Level } & \multicolumn{2}{c|}{$1^{\text {st }}$ difference } \\
\cline { 2 - 5 } & $\tau_{\mu}$ & $\tau_{\tau}$ & $\tau_{\mu}$ & $\tau_{\tau}$ \\
\hline USD & 1.1818 & 0.1367 & $-6.0040^{*}$ & $-6.2600^{*}$ \\
SGD & 0.8441 & -1.6728 & $-7.2103^{*}$ & $-7.5649^{*}$ \\
GBP & -1.1368 & -2.1542 & $-6.4872^{*}$ & $-6.4792^{*}$ \\
REER & -2.1130 & -2.6805 & $-4.2440^{*}$ & $-4.2310^{*}$ \\
\hline
\end{tabular}

* Statistical significance at 0.01 level. $\tau_{\mu}$ and $\tau_{\tau}$ are standard ADF tests with a constant and a constant with time trend included in the equation, respectively. 
Then, Table 3 reports $d$ estimates for all four real exchange rates along with asymptotic standard errors and the associated $p$ values for the unit root null hypothesis $(d=1)$. The number of low-frequency periodogram ordinates included in the GPH regression introduces a judgemental aspect; improper inclusion of medium-frequency ordinates will contaminate the estimate of $d$, while too small a regression sample will lead to imprecise estimates. Table 3 reports $d$ estimates for each series for three different regression sample sizes. The sample sizes are equal to $\mathrm{T} \alpha$, for $\alpha=0.5$, 0.525 , and 0.55 . The estimates of the order of fractional integration are quite robust across this variation.

Table 3

Estimates of $d$

\begin{tabular}{|lrrr|}
\hline & \multicolumn{2}{c|}{$\alpha$} \\
\cline { 2 - 4 } \multicolumn{1}{c}{ Data series } & 0.5 & 0.525 & 0.55 \\
\hline Real effective exchange rate & 0.136 & 0.184 & 0.188 \\
1988:3 - 2002: 6 & $(0.025)$ & $(0.063)$ & $(0.060)$ \\
& $P=0.00$ & $P=0.01$ & $P=0.00$ \\
GBP / MYR & 0.641 & 0.695 & 0.689 \\
1980:1 - 2002:12 & $(0.151)$ & $(0.135)$ & $(0.111)$ \\
& $P=0.00$ & $P=0.00$ & $P=0.00$ \\
USD / MYR & 0.213 & 0.206 & 0.209 \\
1974:1 - 1998:8 & $(0.073)$ & $(0.057)$ & $(0.055)$ \\
& $P=0.01$ & $P=0.02$ & $P=0.01$ \\
SGD / MYR & 0.303 & 0.296 & 0.343 \\
1974:1 - 2002:12 & $(0.087)$ & $(0.073)$ & $(0.079)$ \\
& $P=0.00$ & $P=0.00$ & $P=0.00$ \\
\hline
\end{tabular}

Note: Standard error displays as (.)

The point estimates of $d$ are quite striking, as all are less than unity, and most of them are very much less than unity. The null hypothesis of unit root is rejected in favor of the long memory model. Three out of four real exchange rate series being investigated display mean reversion as $d<1 / 2$. The results suggest that shocks to $r_{\mathrm{t}}$ have finite lives. If shocks to $r_{\mathrm{t}}$ have finite lives, then long run purchasing power parity is a valid equilibrium. The degree of persistence is the highest for pound sterling as the value of $d$ is greater than 0.5 .

\section{CONCLUSIONS}

This paper tested Malaysian monthly real exchange rates for evidence of mean reversion. A semi-parametric estimator was employed in an effort to obtain inferences that are robust to problems associated with non-stationary data. The application of a long memory model associated with the non-integer $d$ to analyze the time series properties of Malaysia's real exchange rates have important implications for the PPP hypothesis as 
there was strong evidence of mean reversion in the data. Evidence of long memory is found in all of the exchange rates studied, though it is not necessarily associated with a unit root, as estimated $d$ values range from 0.136 to 0.689 . Furthermore, the knife-edged cases of 'unit root' and 'no unit root', which correspond to $d=1$ and $d=0$ respectively, lose their exaggerated importance once $d$ is allowed to vary on a continuum. In general, the PPP literature is one of the best examples of how many researchers have been misled by the low power of unit root testing procedures and have tended to abandon PPP without sufficient attention to the econometric procedures.

\section{REFERENCE}

Abuaf, N., \& Jorion, P., (1990). PPP in the long run. Journal of Finance 45, 157-174.

Azali, M., Habibullah, M. S., \& Baharumshah, A. Z., (2001). Does PPP hold between Asian and Japanese economies? Evidence using panel unit root and panel cointegration. Japan and the World Economy 13, 35-50.

Baharumshah, A. Z., \& Ariff, M., (1997). Purchasing power parity in South East Asian countries: A Cointegration approach. Asian Economic Journal 11 (21), 141-153.

Baillie, R. T., \& Selover, D. D., (1987). Cointegration and models of exchange rate determination. International Journal of Forecasting 3, 43-53.

Cheung, Y., (1993). Long memory in foreign exchange rates. Journal of Business and Economics Statistics 11, 93-102.

Cheung, Y., \& Lai, K. S., (1993). A fractional cointegration analysis of puchasing power parity. Journal of Business and Economics Statistics 11, 103-112.
Diebold, F. X., Husted, S., \& Rush, M., (1991). Real Exchange rate under the gold stan dard. Journal of Monetary Economics 24, 151-178.

, Rudebusch, G. D., (1989). Long memory and persistence in aggregate output. Journal of Monetary Economics 24, 189-209.

Frankel, J. A., (1986). A panel project on purchasing power parity: mean reversion within and between countries. Journal of International Economics 40, 209-224.

, \& Rose, A. K., (1996). A panel project on purchasing power parity: mean reversion within and between countries. Journal of International Economics 40, 209-224.

Geweke, J., \& Porter-Hudak, S., (1983). The estimation and application of long memory time series models. Journal of Time Series Analysis 4, 221-238.

Glen, J. D., (1992). Real exchange rates in the short, medium, and long run. Journal of International Economics 33, 147-166.

Granger, C. W. J., (1980). Long memory relationship and the aggregation of dynamic models. Journal of Econometrics 14, 227 238 .

Hakkio, C. S., \& Rush, M., (1991). Cointegration: how short is the long run? Journal of International Money and Finance 10, 571581.

Huizinga, J., (1987). An empirical investigation into the long run behavior or real exchange rates. In: Brunner, K., Meltzer, A. H.(eds.) Empirical studies of velocity, real exchange rates, unemployment and productivity. North Holland: Amsterdam.

Khoon, G. S., \& Mithani, D. M., (2000). Deviation from purchasing power parity: Evidence from Malaysia, 1973-1997. Asian Economic Journal 14 (11), 71-85. 
Lothian, J. R., \& Taylor, M. P., (1996). Real exchange rate behavior: The recent float from the perspective of the last two centuries. Journal of Political Economy 104, 448510.

Oh, K. Y., (1996). PPP and unit root tests using panel data. Journal of International Money and Finance 15, 405-418.

Papell, D. H., (1997). Searching for stationarity: PPP under the current float. Journal of International Economics 43, 313-332.
Shiller, R. J., \& Perron, P., (1985). Testing the random walk hypothesis: Power versus frequency of observation. Economic Letters 18, 381-386.

Taylor, M. P., \& Sarno, L., (1998). The behavior of real exchange rates during the postBretton Woods period. Journal of International Economics 46, 281-312.

Wu, Y., (1996). Are real exchange rates non-stationary? Evidence from a panel data test. Journal of Money, Credit and Banking 28, 54-63. 